\title{
Martin Luther: Unexpected Dimensions of Freedom
}

\author{
Hans-Christoph Askani
}

It must surely be something quite different

which brings religion and freedom to the soul. ${ }^{1}$

\section{Introductory Remarks}

The topic of the present volume is theological anthropology, 5 oo years after Luther, in the form of a dialogue between Orthodox and Protestant theologians. In order to interact with my colleague Konstantinos Delikostantis, I was entrusted with the task of reflecting on Christian freedom as it is understood in the context of Lutheran anthropology. To comply with this, I will proceed from the short but important book of the Reformer, which already contains the term "freedom" in its title. My aim is to present the ideas developed in this book and thus contribute to an exchange and, I hope, a better mutual understanding between Orthodox and Protestant theology.

Freedom - in its meaning, its scope, and also in its limits - is one of the great themes of philosophical and theological anthropology. The title of the book suggests that Luther develops in it a Protestant contribution to a general anthropological problem which should be of interest to anyone who thinks about the human being and his freedom.

1 Martin Luther, "The Freedom of a Christian," in Reformation Writings of Martin Luther, ed. and trans. Bertram Lee Woolf, vol. 1. The Basis of the Protestant Reformation (London: Lutterworth Press, 1952), 356-79, here $35^{8}$ (\$4). In German: "Es muß noch alles etwas ganz anderes sein, was der Seele Frommheit und Freiheit bringt und gibt." Martin Luther, "Von der Freiheit eines Christenmenschen," in Martin Luther ausgewählte Schriften, ed. Karin Bornkamm, Gerhard Ebeling, and Oswald Bayer, 2nd ed. (Frankfurt: M. Insel, 1983), 238-62, here 240 .

(C) HANS-CHRISTOPH ASKANI, 2021 | DOI:10.1163/9789004461253_008

This is an open access chapter distributed under the terms of the CC BY-NG-ND-4nolicense. Askani - 9789004461253 
However, it is not evident that this is the case. If we place ourselves in the great philosophical tradition since the Enlightenment, then freedom appears to us as one of the cornerstones that sustain and found the identity and dignity of every human person. In the context of this tradition, "freedom" is understood as the possibility and ability of human beings to decide autonomously. On the basis of this understanding, every human being has an incomparable and inalienable value. Accordingly, in what deeply concerns him, no other person has the right to take his place and make decisions for him. The first thesis that Luther formulated right at the beginning of his book - "A Christian is free and independent in every respect, a bondservant to none" 2 - sounds quite modern in this context.

For unbiased ears, it sounds as if Luther is protesting against false authorities and speaking out in favour of a liberation that awards man his inviolable dignity, places him before his responsibility and calls him to take his existence, with all its imponderables, into his own hands. It seems that Luther is anticipating one of the great orientations of modernity. The reader, however, who continues to read the book, will see that the Reformer is disappointing the expectations so directed.

When we ask the question today of the actual meaning of "freedom" in general terms, then we tacitly assume two premises: a) freedom is one of human beings' essential attributes; b) we basically know what it is: even if we cannot explain how it works, and under which conditions it is possible, we have an inner experience that we are free, that we are responsible for our deeds.

For Luther the question is different; despite the fact that he dedicated two of his most important works to the theme of freedom, ${ }^{3}$ it is not at all self-evident for him to speak of freedom in relation to man; nor is it evident to him what it actually consists of.

It is quite possible, yes, it is even probable, that Luther's famous treatise of 1520 , and that the Reformation, understood as a historical event, had a not inconsiderable influence on the modern understanding of freedom. But that does not change the fact that it was by no means Luther's intention to contribute anything at all to this understanding of freedom - at least this is the thesis that comes to mind after reading the treatise attentively. I would even like to go one step further and say that the modern understanding of freedom, as the human being's unrestricted self-determination, is basically of no interest to Luther.

2 Luther, "The Freedom," 1952, §1. In literal translation: "A Christian is a free lord of all things and subject to no one" (my translation).

3 Beside The Freedom of a Christian (1520): De servo arbitrio (1525). 
This lack of interest, if I see correctly, in fact concerns all anthropological questions, as long as they are perceived as purely anthropological. What Luther really aimed to understand was the relationship between God and man, and within that relationship - but really only within it - the understanding of the human as well as his freedom.

Thus the question Luther is concerned with is not that of a general concept of freedom, but whether recourse to freedom is inevitable as we ponder the relationship between God and man; and if so, why. According to Luther's theology, the answer to this question is clear: Yes, we must consider "freedom" if we want to think God and man together. However, the answer given so quickly risks remaining superficial. To really understand whether and, if so, why Luther cannot do without the concept of freedom when he wants to think of the relationship between God and man, is a complex and surprising undertaking. The following reflections are intended to meet this challenge.

\section{First Reading}

1.1

Another Freedom

We saw that when Luther thinks about freedom, it is because without it the relationship between God and man cannot be understood. This thesis, stated in such general terms, does not sound surprising. Indeed, the importance of freedom for the relationship between God and man can be situated on several levels: a) at the level of a theology of creation, according to which the human is created in the image of God, which distinguishes him among all creatures as the only one gifted with reason and freedom; b) at the level of a soteriology, according to which the human is called to respond to God's will in free obedience, thus contributing to his salvation; and c) finally, in ethical terms, in which the freedom of the human is presupposed as the basis of his responsible action.

The treatise The Freedom of a Christian makes us understand that Luther, rather surprisingly, places freedom, when he considers it in its crucial aspect, on a different level, and that he speaks of it in a very different tone. On the three levels just mentioned, the theological meaning of freedom is easily understood. For Luther, on the other hand, the freedom of the human, understood theologically, is everything but obvious. This is already reflected in the apparent contradiction of the two theses, which open the book: "A Christian is free and independent in every respect, a bondservant to none. A Christian is a dutiful servant in every respect, owing a duty to everyone." ${ }^{4}$ Continuing

4 Luther, "The Freedom," 1952, 357. In German: "Ein Christenmensch ist ein freier Herr über alle Dinge und niemand untertan. Ein Christenmensch ist ein dienstbarer Knecht aller Dinge und 
to read, one becomes aware that the apparent contradiction is in fact nonexistent, but the impression remains, and remains true, that freedom is not an unquestionable evidence, but on the contrary an "object of dispute," of conflict-laden relationships.

If one considers the context in which each of the two theses has its place and meaning, one becomes aware that there is a tension not only between the two theses, but within each of them, without which their content would have no meaning at all. The crucial step in understanding this tension is to discover that for Luther freedom is a relational event, and that in it freedom and bondage are inextricably linked. Accordingly, the first thesis, which seems to be devoted exclusively to freedom - without this being explicitly stated already implies a bondage; and the second, which places the subjugation of the Christian in the foreground, presupposes - again without this being explicitly articulated - the event of liberation.

According to Luther, the human - in his theological understanding - is who he is, not in himself; he becomes who he is, in relation to ...: in relation to other human beings, in relation to himself, in relation to God. ${ }^{5}$ We were talking about conflict-laden relationships in this regard. They are conflict-laden simply because of the fact that they are diverse. The human being simultaneously lives different relationships, relationships which are constitutive for his being and which - each in their own way - assert diverging claims. This is exactly what Luther's book is about, and his understanding of freedom has its controversial foundation and its precarious challenge right here. Why "precarious"? Because none of the relationships is without the others. The question of who the human is in relation to himself is at the same time the question of who he is in relation to God, and who he is in relation to his fellow human. Thus the question of freedom is the question of these different relationships that cannot be reduced to one another and yet are simultaneous with one another. This is reflected not only in the content, but also in the structure of the book, which is marked out by the two theses quoted above. They speak, as we have emphasized, of being free and of being bound. So we can already say: according to the first thesis, the human is "free" and "Lord" because he does not belong to himself but to God; according to the second thesis, the human is "servant," because God has liberated him so that he can open himself to the one who needs him.

jedermann untertan." Luther, "Von der Freiheit eines Christenmenschen," 239. In a literal translation: "A Christian is a free lord over all things and subject to no one. A Christian is a dutiful servant of all things and subject to everybody" (my translation).

5 In his famous Disputatio de homine (1536), Luther shows explicitly how, in a philosophical understanding, the human being can be understood as he is in himself, whereas in a theological understanding the human being must be understood under the perspective of the relations in which he lives (and dies). 
The title of the book The Freedom of a Christian, in connection with its reputation as one of the great Reformation writings, probably contributed to a not inconsiderable misunderstanding. According to this misunderstanding, this is a text that proclaims Protestant liberation in relation to the ecclesiastical constraints of typical Roman provenance. But that is not the case. Luther's treatise speaks, as we have already seen, of another and deeper liberation that affects every Christian in her innermost relationship with God.

Despite the intimate character of this freedom, it is not something "in" the human - a quality, a characteristic that would constitute the human's dignity; no, instead of finding itself in the human, it finds itself between God and the human. There it takes place: in the relationship between the two; and so it also belongs to both at the same time: God and the human. God gives it, the human receives it. This means that it is not simply freedom, but liberation.

The human as a Christian is liberated. But did he need to be freed? Was he imprisoned? The great discovery of faith, according to Luther, consists indeed in a double knowledge. In faith the human recognizes that he is liberated and that he was imprisoned. He recognizes both, in one and the same discovery. Why in one and the same discovery? Because he would not have been able to imagine the nature and extent of his imprisonment, had he not experienced his deliverance.

But what is he free from? Different answers can be and have been given throughout history. In philosophy: on the one hand man is freed from external constraints such as slavery, bondage, totalitarian regimes, prohibitions of all kinds, on the other hand from internal constraints such as his desires, fears, illusions and his excessive demands ... In theology: the human is freed from sin, despair, injustice, loneliness, fascination with death ... The specificity of Luther's theology consists in the following fundamental thesis: All these answers are true, but they are enclosed in and overtaken by another: the human is - through God - liberated from himself. How is that? Why should the human be freed from himself? Because he tends, and inevitably tends, to define himself through his claims, his illusions, his sin, his despair, his injustice and his tendency to death. In short, because he has the tendency to understand himself by short-circuiting himself, that is, by referring only to himself and thus enclosing himself in himself. Augustine called this the "pride" of the human, his self-assertion, his will to find and have everything in himself: his origin, his destiny and his meaning.

But who is capable of freeing the human being from his self-assertion, which in truth is a self-enclosing of oneself in oneself? The answer sounds 
banal and trite, but it is not: No one and nothing else can free man from himself but God. Why that? Because the relationship that man maintains with himself is (as he thinks) a complete relationship, a relationship in which he is completely absorbed. And it is all the more complete because it draws God into this self-relationship. But the more complete it is, the more closed it is. So the human refers to God, but he instrumentalizes God. Theology sees this more precisely than any other science. The human, as theology shows, desires two things: on the one hand he wants to realize himself, on the other hand he wants to impress God. In order to realize and complete himself, he wants to impress God. And to impress God, he thinks he has to accomplish himself. Thus God becomes a function of man. In order to be able to find and take his own place, he thinks he must also take God's place. Without him being God - that is his deep and silent conviction - he would not be himself. No one can liberate the human from this God-impressing desire other than God himself.

Therefore we interpret freedom as liberation. The shift of one to the other is the meaning of the Christian understanding of freedom. Throughout his entire existence, the human seeks a place that is his, that corresponds to him. Where is this place? In the infinity of his claims (wanting to be everything in order to be himself), or in the limitation granted by faith (receiving the meaning of his existence from another)? That he may find the place of his existence in the limitation of himself, instead of in the infinite expansion of himself, is the event of the most fundamental liberation that can happen to the human. That is why Luther, where he is interested in freedom, is interested in liberation.

At the beginning of our reflection, we said that it was inevitable for Luther to refer to the concept of freedom in order to think of the relationship between God and the human. And we were wondering why. Now we can answer: Because without the liberation that God grants the human, the human would seek his place everywhere, but not where it belongs to him in truth, namely before God.

With this we have gained an important insight into Christian freedom. It is about nothing less than the fact that the human is human. And the human is human if he is not God and does not need to be God. In other words, if he does not have to take his place in God's place; if, on the contrary, he is freed to find his place in relation to God (because God gives him that place). To find one's place before God (coram Deo) is to be free. To be free is to take one's place before God.

So there is a very brief answer to the question of what human freedom ultimately consists in: human freedom consists in the right of the human not to have to be God. 


\subsection{Relation to Myself and to What Is Not Myself}

Freedom is understood in the everyday superficial sense as an external relationship: I am free if no obstacles are placed in my path that prevent me from doing what I want to do or what I decide to do. The philosophical reflection on the other hand has long thought that freedom can and must be in a crucial sense a relationship to oneself. Socrates, for example, feels freer when he takes death upon himself and pursues nothing but his own righteousness than when he escapes death and thereby becomes an unjust person. Kant led the concept of freedom as a relationship to oneself to its apex. I am truly free only if I want the good - and nothing else - and thus when neither an external nor an internal power (such as inclination, lust, fear, etc.) can determine my will.

For Luther, freedom is an external relationship and (at the same time) a relationship to oneself. In the way he grasps the relationship between external and self-relationship, he radically distances himself from both the everyday and the philosophical understanding of freedom outlined above. According to Luther, the reason for true freedom does not lie in conditions that do not hinder me; but it is also (as already indicated) neither a quality nor the main characteristic of the human as such in the sense of the thesis: "To be a person means to be free," or: "Man is free from nature."

According to Luther, the reason for true freedom lies in the relationship of the human to God and of God to the human. This relationship, which can and must be read in two directions, establishes the human's self-relationship in his external relationship.

While it is true that only a certain relationship of the human to himself makes his relationship to God possible, it is even more true that only a certain relationship of God to the human makes his relationship to himself - and therefore also to God - possible.

In concrete terms, the human can only relate to God when he is liberated from himself, but can only be liberated from himself when God's relationship with him precedes his relationship with himself, that is, when the human allows God's relationship with him to be more fundamental than his (the human's) relationship with God.

6 In this second reading, topics that were already addressed in the first will be dealt with in greater depth. 


\subsection{Lord and Servant}

The two initial theses of Luther's treatise on freedom make no sense without taking into account the reciprocal relationship between external relationship and self-relationship: "A Christian is a free lord over all things and subject to no one. A Christian is a dutiful servant of all things and subject to everybody" ( $\$ 1)$. We have already indicated that there is not only a tension between these two theses, but also a tension, even a conflict, within each of them.

What are the different elements of the conflict? One might think that it takes place between two ways of being, both of which apply to Christians: To be lord and servant. However, it is interesting to see that these two ways of being contradict each other only superficially; in reality they basically complement each other and correspond to each other. For if the conflict really took place between them, then the interest would be to resolve it, and to do it - obviously - in favour of the side of lordship (being master). The ideal of Christian life would be that he is no longer a servant, but only a lord. But this is not what Luther means to say (neither is it what Paul said), because both being lord and being a servant are simultaneously valid in his approach. So what matters is something else, namely being lord in the right way and being a servant in the right way. This shows that if there is a conflict here, then it is not simply between being lord and being a servant, but somewhere else. It lies in the question of who "defines" lordship and servitude.

The human being wants to determine by himself who and how he is lord, and again God wants to determine by himself who and how he is lord (how God is Lord and how the human is lord). Thus, the tension that is ultimately at stake is between God's claim and the human's claim, more precisely: how God deals with his claim, and how the human deals with his claim. More precisely, the tension is how God deals with his claim in relation to the human's claim, and how the human deals with his claim in relation to God's claim.

This brings us back to the relationship between being free and being bound which we mentioned above. The human, in his non-believing selfunderstanding, assumes that he is only free if no one besides himself binds him. The Christian, in his believing self-conception, accepts that she is only free if God binds her more than she binds herself. In this way, freedom and attachment mutually reinforce each other.

This can be illustrated by Luther's two initial theses. According to the first thesis, man is free because he is bound by God and to God (i.e. because he belongs to God and not to himself); according to the second thesis, man is bound because he is freed by God (i.e. again because he belongs to God and not to himself, but therefore belongs at the same time to his neighbour). To 
sum up, both can be said: man is bound by God, freed from himself in order to be bound as a free man - by God and his neighbour. He is therefore freed twice and bound twice - which is doubly pointless for a conventional concept of freedom: first, because attachment, considered superficially, does not free but is the opposite of freedom, and second, because it does not require double freedom nor double attachment. If Luther nevertheless speaks of a reciprocal relationship between freedom and commitment, and if he also speaks of a double freedom (and a double commitment), it is because freedom is an event that commits the human person in manifold relationships. In these diverse relationships, freedom does not diminish proportionally as attachment increases, but rather finds itself in this attachment.

Taking into account the various circumstances in which the human person finds himself, we can summarize: Man's self has its reason and its goal not in himself; rather, it comes to him, and thus, coming to him, it cracks open the human beyond himself.7 The human's relationship to himself begins - and always begins anew - in God and takes the human into the events of this beginning. But just as it does not begin with the human himself, so it does not stop with him. It passes from him to his neighbour, and thus also takes the neighbour into the event of this divine beginning. (Whoever this "neighbour" is at all becomes clear exactly in this transition.)

He is recognized as neighbour simultaneously by God and by man.

\section{3 "Body" and "Soul"}

It is not possible to grasp the Christian concept of freedom in its depth without taking into account a difference, even a dichotomy, which Luther introduces already at the beginning of his treatise (in the second paragraph): the distinction between soul and body. He takes it from the tradition, but gives it a direction which is new. As he sees it, soul and body mean the whole human being, but in different determining relationships. Anticipating insights which will become clearer below, we can say: "soul" is the determining relationship in which the human is free; "body" is the determining relationship in which the human is not free. Hence, whether man is free or not depends on how he situates his relationship to himself in relation to God:

"Soul" is the name of the human's relationship to himself, insofar as he understands himself "from" God.

$7 \quad C f$. the very end of the book: "From all the foregoing, the conclusion follows that a Christian lives not in himself, but in Christ and his neighbour; in Christ by faith and in his neighbour by love. By faith he rises above himself unto God; from God he stoops below himself by love, and yet he remains always in God and in divine love [...]." (§30.) 
"Body" is the name of the relationship of the human to himself, insofar as he understands himself "from" himself - which means under the exclusion of God.

(We have explained above how the human's self-understanding excludes God, insofar as the human person makes God a function of himself. And God, who is brought into the arena of man's claim, no longer is God.)

The human stands in both relations, his being human is the carrying out, the embodying of these two relations. Consequently, one must say: the human does not have a body and a soul. Rather, the human is a body and a soul. Hence, since body and soul are not components of human nature, but fundamentally different, even contradictory orientations of the human and of being human (toward God, or toward himself), the human person stands in relation to himself in a tension, even in a contradiction. He has to live this contradiction. His being in the "body" (in the "flesh") does not cease only because the human is also soul; just as his being soul does not cease only because he is also body. The body, if it is an orientation of human existence, does not simply rest within itself, but faces the question of whether and to what extent it closes itself to the spiritual life, to the life of the soul. Just as, conversely, the "spiritual" life faces the question of the extent to which it encompasses and determines the whole of human existence (including the body). The terms "body" and "soul" each have a double meaning: on the one hand, they designate the two extreme poles of their relationship; on the other hand, they denote their radiating range, which concerns also the other pole.

According to these two meanings - as a static, final point of reference, and as dynamic engagement - the human being carries out the relationship of body and soul in himself (in his body and soul). Where bodily existence opens up, not only something is added to it, but bodily existence, without ceasing to be such, is recognized and lived as belonging to a past reality. Where, conversely, bodily existence closes itself off, it does not only remain with itself, but insists on remaining with itself and on already assuming total reality in its relationship to itself.

Because body and soul belong together (as long as man lives), freedom for the human person means liberation. He is liberated from his self-relationship as "body," which is sufficient in itself, to the "spiritual" life of the self-relationship which is not sufficient in itself, but sufficient only in relation to God.

This liberation is a contradiction to man's self-understanding, which according to a purely anthropological conception tends to the effect that the human does not only not need God, but that the less one needs anything other than oneself, the freer one is at all. This "anthropological" understanding is contradicted by the "theological" or "Christological" understanding. This implies 
two things: a) anthropology as such (anthropology grounding itself in itself) is theologically not ultimately relevant; b) from theology or Christology, another (new) anthropology opens up.

To understand oneself as a human being in relation to Christ means understanding oneself as a relationship between body and soul, in which the soul, in its conflict with the body, wins the victory by letting herself be defeated by God. On the other hand, it means understanding oneself as the relationship between body and soul, in which the body allows itself to be freed from its selfsufficient self-reference, which prevents and denies the life of the soul.

This statement is bound to be misunderstood if body and soul are understood as purely static quantities, and not instead as relational poles. Accordingly, in a theological and Christological perspective, the decisive point is not a question of the soul getting rid of the body, but of being redeemed from the body's selfsufficient self-reference, which is called "bodily life."

\section{4 "Free" and "Joyous"8}

In contrast to Kant's philosophical proposal, the concept of freedom can be broadened and explained here (with Luther) by other concepts. In so going, the absolute character the concept of freedom enjoys in Kant's philosophy is modified. In Kant, freedom has its peculiarity in the fact that it is nothing else than the unmitigated autonomy that establishes itself and seizes itself. Indeed, with Luther, a whole series of other words revolve around the word "free," each of which - with different emphasis - means the same thing. So in particular the words "religious and righteous" ("fromm und gerecht"). ${ }^{9}$ According to the common understanding, "religious" and "just" ("righteous") are not only clearly

8 In German: "Frei und fröhlich."

9 See $§ 6,10$ and 11. It represents a real problem, how to translate the German word "fromm," which occurs several times in Luther's text. Surprisingly it is even expressed in relation to God (§11): "So auch wenn die Seele Gottes Wort fest glaubt, dann hält sie ihn für wahrhaftig, fromm und gerecht. [...] denn sie zweifelt nicht daran, daß er fromm, wahrhaftig in allen seinen Werken ist." Woolf translates saying "religious" or "devout." This does not correspond to what the German text says. In his French translation of Luther's treatise, Philippe Büttgen translates "wahrhaftig, fromm und gerecht" with "véridique, juste et droit." Martin Luther, De la liberté du chrétien. Préfaces à la Bible, trans. Philippe Büttgen (Paris: Seuil, 1996), 39. Büttgen's translation corresponds to the ancient meaning of the word "fromm" ("vrum," "vrom") as it was used in the Middle Age: "tüchig, trefflich, tapfer, rechtschaffen" (See Der große Duden, Etymologie. Herkunftswörterbuch der deutschen Sprache (Mannheim: Dudenverlag, 1963), 187.) It is important, however, to take into account that, in the 15th century, the word "fromm" shifts to its modern meaning. This development has important implications in Luther's theology: what is at stake here is a mutual relation, in which God and the human refer to each other in an utterly reliable way. 
different from each other, they also mean something completely different than "free." To be religious as well as to be righteous are, in themselves, attitudes or qualities of a person. As attitudes or characteristics of humans, they are clearly differentiated, which does not even need to be explained. If they are to coalesce in their meaning, as they do with Luther, they must be understood from a perspective that does not conceive the human only from what he is in himself. That is exactly what Luther suggests.

Since, in contrast to Kant, Luther shifts freedom out of the human's being in himself into a relationship which God begins with human beings, and which God accomplishes for them, he cannot (!) use the word "free" in abstraction from other concepts. Other words, which also describe this relationship, can and must appear next to the word "free," so that the relationship prevailing here may be all the more explicitly expressed. As terms that indicate what is at stake between God and human beings and what God has decided for them (namely, what God has decided for both God and man), words such as "free," "righteous," "truthful," "gracious" or "joyous" interlace. ${ }^{10}$ The reason for the language's expansion, which happens here in a quite natural way, is that the relationship at hand has already been decided by God, and therefore must not first be sought and reached by the human person, but has only to be received and accepted in its fullness or superabundance. The fact that it can only be received (and not produced or established) is precisely a consequence of this relationship of superabundance.

To the fullness of the events corresponds the fullness of the expressions. According to Luther, the human person's relationship with God changes from a relationship of lack, inadequacy and distance that can never be filled, into a relationship of surplus and participation. To describe this sharing and participation, as we have seen, a plurality of - at first sight very different - words that explain each other can be put to use. On the other hand, each of these words expresses the whole matter. That someone is "just" ("righteous") before God is his "freedom." According to Luther there is no other freedom than that, that one may exist before God (because God grants one this "right," this "justice"); that he is "free" is again his "righteousness" (which consists in recognizing God as "righteous," namely as the one who makes the human free and just (righteous)). That he is "righteous" and "free" finally makes him "joyous" (a joy which, when all is said and done, is the very essence of his relationship to God). Everything depends on not understanding the expressions as elements of an enumeration, but on grasping them in their interplay.

10 See $§ 10-12$. 
In the context of Luther's Freedom of a Christian, the relationship between justice and freedom is most often highlighted. There is actually only one "unfreedom" before God: it consists in the fact that one is unjust (without any right) before God and has to struggle for one's justice as if it were a question of life and death. However, this struggle is, in theological perspective, not a liberation from injustice; it leads, instead, to an ever deeper entanglement within it. Such a statement is nonsense from a purely anthropological point of view. But the decisive thing is precisely that Luther speaks theologically, and not anthropologically; and that, according to him, the theological sense does not build upon the anthropological, but replaces it. More cautiously said: the theological sense determines and interprets the anthropological sense - interpreting it thoroughly. That one is always unjust before God is therefore said for the sake of God's relationship with the human. One can say it more precisely: that one can only be unjust before God on one's own initiative is no less a statement about God than about the human. It is a statement that has its punch line in that it brings God into play. Where anything else would or could be said about the human besides the fact that he is profoundly unjust before God, God would be eliminated.

Luther can therefore also trace the question of one's freedom back to the question of whether the person honours God. To honour God means to attribute to God being "good and true."11 But if one attributes "truth and all goodness" to God, one cannot attribute it to oneself. Then how can anyone be simultaneously "righteous," "free" and "joyous"? The answer is: one cannot. The only possibility lies in the fact that he recognizes that "all truth and all good" are God's, and not his. This attribution is the human being's freedom, justice, and joy. It is God who takes the human's relationship to God in his hand and holds it in his hand. Only faith can understand that. In fact, faith is nothing else than this understanding.

Third Reading

4.1

"Two Natures"

As we have already seen, Luther speaks of a double, ambivalent nature of the Christian: "[...] we ought to remember that in every Christian there are two

11 §11. See "Thus also, if the soul firmly believes in God's word, she holds Him trustworthy, good, and righteous; and thereby she pays Him the greatest honour in her power. For then she acknowledges Him to be in the right, obeys His law, and honours His name, and lets him do with her what He will [...]." (362; §11) "For God is not honoured unless truth and good and all are ascribed to Him, their true source. Meritorious works do not make that ascription, but only genuine faith." (364; §13). 
natures, a spiritual and a bodily." ( $\$ 2)$ One has become accustomed to accepting that the human is constituted of two different natures. But if one remembers that the term "human nature" encompasses and names the whole of the human person (even if it contains various "components" or aspects), then it becomes clear how surprising Luther's mode of expression is. It not only contradicts the tradition, but it also upsets a spontaneous understanding. The term "nature" implies a unity, a unit that is what it is. But this is exactly what Luther wants to deny. He inserts into the expression "nature" a tension that goes beyond its original meaning.

It is to be noted, however, that Luther (differently from the brief summary above) does not speak of a "twofold nature" of the human person, but of a "twofold nature" of the Christian. This is the case in the German version; the Latin version speaks, as it seems, in a different way, but its meaning is the same. According to Luther, the human being is of two natures, and it is in the Christian that we see what this means. This is indeed the point at which Luther's new approach becomes quite manifest: he does not include "being a Christian" within "being human," but, conversely, understands "being human" from "being a Christian." Thus, what he develops and what he is interested in, is not anthropology, but Christo-anthropology. In fact, those who read Luther's text attentively become aware of how the theological view, or the theological approach, conflicts with the usual use of words. These words, in their proper intention, are no longer in a position to say what they should say. This impossibility must come about, and it must be carried out and presented itself in them - in these words. This is exactly what is happening, in an exemplary way, in relation to the notion of "nature"; but it has also happened, as we have seen, in relation to the notions of "soul" and "body," and, in fact, in relation to all the notions that are crucial to the thought process of the book.

What does it mean to speak of "two natures," of a "twofold nature"? Flowing from what has just been said, it cannot be a matter of a "natural condition" according to which (and within which) the human is, so to speak, composed of various elements - such as body and spirit, body and soul, etc. Rather, his whole nature is "two different things," so that there are not different elements joined together in order to form one nature. In the human as a Christian, two natures are joined together. This is what makes the Christianity of the Christian and the humanity of human beings. Strictly speaking, the expression "two natures" is almost a contradiction in itself. The humanity of the Christian, however, constitutes itself as this contradiction, as this tension which the Christian carries out, or which carries itself out in him or with him.

The two natures are the "spiritual" and the "bodily." In principle, they are relationships, more precisely: conflicting relationships. The whole of the person is to be understood ambivalently: according to his bodily or spiritual 
reality. "Either/or." Innocence is not possible. The spiritual life is in conflict with the bodily life. To live "spiritually" means to contradict the "bodily" life, to live "bodily" means to understand nothing of the "spiritual," and therefore to exclude it.

The either/or (spiritual or bodily), however, is not everything here. For, at the same time, the person is always both. He is, as Luther says, "of two natures." He is body and soul. ${ }^{12}$ In this respect, a "this as well as that" (rather than an "either/or") applies. If there is anything to learn for anthropology in Luther's theology as developed in his treatise on The Freedom of a Christian, it is that the human person, where he comes into relationship with God, loses his unity, and nevertheless has to live as one whole, single person. The astonishing thing is that it is not a sick, torn person who comes out of this conflict, but a "joyous" person. The human owes this to Christ. The human being's Christianity - and also the human's humanity - is due to Christ.

The characteristics with which Luther describes the two natures seem plausible at first glance, but on closer inspection they also reveal themselves as astonishing. "In far as he possesses a soul, a Christian is a spiritual person, an inward, regenerate self; and in as far as he possesses flesh and blood, he is a sensual person, an outward, unregenerate self."13

The catchiness of these formulations stems, among other things, from the fact that the words are familiar to us from the Bible. The astonishment becomes noticeable only when one tries to really consider them and put them in relation to each other. There is a hint towards a deeper understanding which is crucial here, namely the sequencing of the different attributes in the sentence. In fact, the six attributes that Luther introduces here can be read in a horizontal or vertical relationship. Either: spiritual - new - internal vs. bodily - old - external (horizontal). Or: spiritual/corporal; new/old; internal/ external (vertical). Both must be done, for the meaning of each individual word is determined by its relatives and its antonym. If one limits oneself to the vertical (bipolar) reading, which suggests itself on the basis of the unambiguous correspondences, one is almost automatically led to an inner-anthropological interpretation. But we have already seen that this is not sufficient. Therefore, a horizontal reading must form the counterweight to it, according to which

\footnotetext{
12 The word "soul" is introduced in the following sentence and indicates the "spiritual nature."

$13 \$$. In German: "Nach der Seele wird er ein geistlicher, neuer, innerlicher Mensch genannt, nach dem Fleisch und Blut wird er ein leiblicher, alter und äußerlicher Mensch genannt" (§2). Literal translation (my translation): "In regard to his soul, he is called a spiritual, new, inward person; in regard to his flesh and blood, he is called a sensual, old and outward person."
} 
"spiritual, new, internal" as well as "bodily, old, external" each mean a whole, a context in which the terms explain and deepen each other's meaning. Then a dynamic may be heard which points beyond the human being as it exists in itself.

\section{2 "Spiritual," "New," "Inward"}

What does "spiritual" mean, in Luther's conception? In order to understand it, we must go back to the German terminology, namely the difference between "geistlich" and "geistig." "Geistig" ("intellectual") means a dimension which, in contradistinction to the material dimension, is regarded as a "higher" reality. But this is not what Luther is interested in here. On the other hand, we must distinguish "geistlich" from what we call nowadays "spiritual," "spirituality." "Geistlich" means something like a bundling of the whole existence, which exposes itself to questions such as where it wants to turn, what its ultimate meaning may be, and with what criterion it makes decisions. This bundling, this concentration and orientation does not come from existence itself. It is something which existence receives. The Jewish theologian Leo Baeck, in his essay "Mystery and Commandment," speaks in an astonishing twist of the human being who receives "mystery" (what is meant here is the mystery of one's existence granted by God). The point, following Baeck, is that one receives this mystery in hearing and listening. ${ }^{14}$ This way of receiving is meant by Luther's word "geistlich," in the sense that one lets a reality come to oneself and decide about oneself, a reality that, conversely, requires oneself so that a decision may occur: a decision which is greater than oneself.

Flowing from these reflections, the second term - "new" - also becomes intelligible. What human life ultimately finds its meaning in, is not produced by the human being himself. It comes to him, he receives it, because he receives

14 Leo Baeck, "Geheimnis und Gebot," in Wege im Judentum. Aufsätze und Reden (Berlin: Schocken, 1933), 33-48. "Wenn der Mensch zu seinem Leben hingelangen will, wenn er nach der Bedeutung seines und alles Lebens hinhorcht, wenn unter der Oberfläche das Wirkliche ihm nahetritt, so erlebt er immer das Geheimnis." (33, my emphasis); for an English translation see Leo Baeck, "Mystery and Commandment," in Judaism and Christianity (Philadelphia: The Jewish Publication Society of America, 1960), 171: "When man wants to be certain of his existence, when he therefore listens intently for the meaning of his life and life in general, and when he thus feels the presence of something lasting, of some reality beneath the surface, then he experiences the mystery [...]." It is interesting to note that in Luther's text the word "hören" also appears at a decisive point. "You may ask however: 'What then is that word which gives such signal grace, and how shall I use it?' The answer is: It is nothing else than the message proclaimed by Jesus, as contained in the gospel; and this should be, and, in fact, is, so presented that you hear your God speak to you." (§6, my emphasis). 
himself. The sense of my existence offers itself to me, seizes me and takes me with it; I would like to say: it "takes me away with it." It takes me away from me - and just so it becomes mine. This event is what the word "new" means in Luther's thought.

This understanding is confirmed by the vertically opposing poles. In contrast to "spiritual" ("geistlich"), which we understood in the sense of a concentration of the whole person, "sensual" ("leiblich") means the dispersion of the person within himself. Because the sensual person does not hear the call (of the "mystery"), because he does not hear the word, he stays with himself and loses himself in his bland selfhood. This is what is meant by "body," "bodily": union with oneself, fulfilment in one's own self.

This again corresponds to the meaning of "old": the "old self" is - theologically speaking - the contradiction against the arrival of that which is inexhaustibly new since it has no other kind of being than that it comes. That it comes to me as to that existence which, in such coming, detaches itself from what it was before. "Old," therefore, in the sense of a past which is no longer valid, no longer true.

It thus becomes clear that both series do not describe the human in himself, but the human in his relationship to God. To be more precise, the human in his relationship with himself and with God. Or even more precisely: in his relationship with himself, insofar as it is inseparable from his relationship with God. For this purpose, the terms mentioned at the beginning of the line set the tone. "Spiritual" ("geistlich") is the self-understanding of the human insofar as he understands himself "from" the relationship with God; "bodily" is the relationship between God and man insofar as man understands himself from his self-understanding. Correspondingly, the human is "new" insofar as he lets himself be understood by God; he is "old" insofar as he not only wants to understand himself, but also God, from himself.

Protestant theologians in particular have always attached importance to the opposition of "old" and "new." It has the advantage that in each case the whole person is meant, and that his old or new being can be thought of as a renewal that comes to him from God (for instance as his "justification," as his new life "in Christ" ...). The opposition "inward"/"outward" destabilizes this, for it can be thought of by every human being simultaneously, and it characterizes him as what he is in himself. (At any rate, it seems to be the case.) That is why it has always been critically suggested that when Luther introduces the opposition "inward"/"outward," he appears to abandon the consistency of his own thinking and to fall back from the level of his approach into old thought patterns.

In fact, it might seem as if the two concepts ("inward"/"outward") are expressing the opposition of the sensual and the intellectual ("geistig"), according to 
which his sensual, "outer" side draws the human person away into the material, into the realm of desires and temporality, while the "intellectual" ("geistig"), "inner" one connects him with the higher world of the ideal, the divine and the eternal. The human being's task would then be to fight in himself and for himself the battle between these two powers (let us say, "darkness" and "light"). However, this purely inner-anthropological scheme of understanding does not correspond to Luther's approach. On the one hand, in his understanding such a dualistic division (body/mind) does not fit with the biblical view of the human person; on the other hand, the dividing line, corresponding to Luther, does not run in the human (between two "parts" of his being), but between the human as a whole, on one side, and God, on the other.

Under this condition, we can draw the terms "inward" and "outward" into the overall conflicting scenario which Luther "builds" in order to better understand what actually happens with the human in the encounter between God and man. So we can say on a trial basis: The "inner" man is the one who takes his soul (here I use the term "soul" to describe this inwardness) so seriously that he opens it to God and lets God into it; the "outer" man is the one who loses himself to the peculiarity of his person in such a way that, even when he goes out of himself, he always arrives only at himself. The human's inwardness is his "soul" open to God, whereas man's outwardness is his "body" uniting with himself, his self-content with himself.

It is important not to fall back again into an understanding according to which body and soul would be components of man. They are orientations of the whole human being. The inner man goes further out of himself, whereas the outer man stays closer to himself. But these two movements are so radically conceived that they become a strict contrast: the inner man goes all out of himself - until he opens himself to God; the outer man stays all by himself until he becomes his own God. But why then this counterintuitive use of the words "inward" and "outward"? Because the "inward man," in Luther's sense, and his turning to the outside, have nothing at all to do with "inwardness" understood in the usual sense. As a matter of fact, Luther's turning outward does not contradict inwardness! According to Luther, the "inward man," when he opens himself up, does not leave himself because of curiosity, distraction, etc.; rather, he opens himself up because he lets himself be opened by God. But what does God open? The human person's innermost. (What else?) - God opens the human's innermost being, which becomes God's in this opening. Thus "inward" and "outward" invert their meaning: The inward is the most open "thing" that belongs to God; the outward is that which remains with itself, in which the human belongs to himself. The "inward" man is the one in whom the Word of God penetrates into the heart of his person; the "outer" man is the 
one in whom the Word of God bounces off the outside before it could penetrate into the "inner."15

Once again, we ask: why the counterintuitive terminology? Because God himself reverses the relations. In other words, because God, not the human being, defines "outside" and "inside." God speaks into the depths of the human. But this innermost part of the human does not yet exist. It is not his interiority, his reason, or his will; it is the place where the human listens to God. So, the "inward" man does not exist prior to this event of encounter, rather, it comes to existence with it. But how? By God speaking into it from the outside. So, what is the "inside" of the human? It is what happens when the human turns everything within his being outwards under God's claim, in order to receive this being in a new way.

And the "outside" of the human person? It is one's concentration on oneself, in which, however wide may be the circles around the person, one draws everything which is outside of oneself into oneself again - even God. In a word: The interior of the human is the caring of God coming to (entering into) the person's own being. The exterior of the human is the pretension of the human swallowing up everything into oneself - even God.

Let us summarize: the interior and exterior of the human become interior and exterior in the encounter with God. God wants the inside of the human. For this God needs it outside; the human wants what is outside (the inside already belongs to him), therefore he takes it into himself. But it is only throughout the fact that God wants the "inner" of the human that the "inner man" is constituted. On the other hand, the outer being also constitutes itself only in relation to God: namely when the human closes his inner being to God.

\subsection{The Soul and the Word}

We are trying to understand what "spiritual" ("geistlich") means. We have spoken of the concentration of the whole person, in which he bundles and aligns his ego, but "bundles" it by opening it. Such opening is the "soul." The spiritual life is the "interior," which "includes" the outermost - God.

The element which can build the bridge from the outward to the inward can only be one: the word (for only the word can open things in such a fundamental way.) The inward reality, which can find its peace only in the outward, can

15 See Eberhard Jüngel, Zur Freiheit eines Christenmenschen. Eine Erinnerung an Luthers Schrift (Munich: Kaiser, 1991), 76: "Das von außen in ihn hereinkommende Wort Gottes wendet den Menschen selber allererst nach innen und unterscheidet ihn dadurch als inneren Menschen von sich selbst als äußerem Menschen." 
again only be one thing: the soul (for only the soul can be involved in such a radical way). So, word and soul belong together.

Luther is not afraid, when he speaks of the "word," to mean the "word of God." Indeed, the expression "soul" would not have been rightly introduced if it would not meet the claim of God. And even God, as the author of the word, would not speak (or be able to speak) if it were not the soul which receives this word. "[W]e can be certain that the soul can do without anything but the word of God; and apart from the word of God it has no means of help. When it has the word however, it has no need of anything else. In short, it possesses food, joy, peace, light, ability, righteousness, truth, wisdom, freedom, and sufficient to overflowing of everything good" $(\$ 5)$.

In fact, it is an exuberant, overflowing relationship between the two. They are both overtaxing themselves. What Jacques Lacan says about love is true here: God gives more than he has. ${ }^{16}$ God gives his word. The soul, in turn, gives more than she has. She gives herself.

There is only one "organ" that understands this double exuberance, and that is almost made for it, namely faith. "I have summed everything up in faith alone, so that whoever has faith, shall have all, and will be saved" (§9).

"Everything ... in faith alone." In fact, for the Protestant understanding, between God and the human, on the part of the human person there can be nothing else than faith. This implies the surprising principle that there can be no cooperation, no working together, between God and the human. The radical nature of this view has led, and continues to lead, to many misunderstandings. One of them is that this approach would be based on a pessimistic anthropology (which is absurd because Luther does not even think in terms of anthropology); another is that faith would then be understood as a sort of "work" between God and the human. But what is special about Luther's conception of the relationship between God and the human is that he overrides the category "work" in order to discover a completely different reality (or vice versa, that the category "work" fades before a completely different reality) that opens up to him. This other reality consists in the relationship between word and faith.

This relationship is to be understood in such a way that only faith grasps the occurrence of the word, and that conversely the word - through faith - grasps (but also forms, creates) the human. By faith, in his faith, man becomes like the word; he becomes what the word says. This is what Luther opposes to the idea of cooperation (even when made possible and "formed" by grace). According

16 "Die Liebe gibt, was sie nicht hat." ("L'amour, c'est offrir à quelqu'un qui n'en veut pas quelque chose que l'on n'a pas.") 
to Luther, this is the only way in which God is really - horribile dictu - "subject" of the relationship to the human. According to other categories, God is not the subject (counterpart), but a player who functions according to the human rules and in which divine grace and human activity are balanced with each other. But where God "comes in," there is no balancing! Either God is all God or not. If God is all God, then what God says is (is reality). And everything else fades in relation to this saying.

What God says applies to the "soul," which becomes like the word that she receives. More precisely: the soul becomes the word that she receives, and that means: she becomes "holy, righteous, true, peaceful, free and entirely good" (§10) "From this standpoint it is easy to see why faith can do so much, and why good works can never be equivalent to it," Luther writes $(\S 10)$. But does not the work also depend on the word? Yes, one can say that, by putting in relationship the work and the commandment. But then the difference to faith becomes all the clearer! The work follows the word (of the commandment); faith becomes what the word makes of it. The one who follows the word of the commandment has his decision in his hands, $h e$ is the "subject"; on the other hand, the one who hears the word and believes (and thus experiences what happens to him) is not the subject: the word alone is the subject. "[W]orks of merit can[not] live in the soul. Only the word and faith exercise sway in the soul."17

"[T]he soul become[s] like the word through its union with the word." (§10), Luther continues. I know of no formulation that summarizes so succinctly, so beautifully and so astonishingly what is decisive in the Protestant faith. If there is to be a truly ecumenical encounter, in which the different denominations would express what is deeply characteristic of their understanding and practice of the Christian faith, then as a Protestant "contribution," this decisive point should be recognized: the word and the soul belong together. This point must be emphasized and cannot be given up. And the instance which carries this out and understands it, is this single reality: faith. This is the reason why not only the soul and the word, but also the word and faith, belong together: "[T] he soul become[s] like the word." This is what faith receives, and what faith lives.

Luther illustrates his thought by the example of the fire and the iron; ${ }^{18}$ shortly afterwards he introduces the image of the bride and the groom. It is the famous passage of the "joyous exchange." We have tried to show how far

17 §1o. In German: “[D]enn kein gutes Werk hängt so am göttlichen Wort wie der Glaube, es kann auch keines in der Seele sein; sondern allein das Wort und der Glaube regieren in der Seele" (§10).

18 "Just as iron becomes red like fire through its union with the fire, so does the soul become like the word through its union with the word. Thus, we see that a Christian has sufficient in his faith" (§10). 
Luther's understanding of "freedom" is removed from the modern notion of freedom as unrestricted self-determination. In anachronistic terms, one could say that he introduced the concept of freedom in his writings in order to show how fundamentally he differed from what freedom became in the centuries that followed. One can say something similar about the concept of the "subject." This concept received only later his modern significance, according to which the human in his self-confidence becomes the Archimedean point of understanding the world. Luther did indeed anticipate some of this concentration, but he did it to turn upside down everything which may be implied within it. What matters to him is not the subject, but the change of subject. And exactly that is what the Christian faith is all about, where it is taken seriously in its depth and height. God and the human change places. Everything that constitutes and weighs upon the human being becomes God's; everything that God brings and gives becomes man's. The human person cannot help but search in desperate struggle for his selfhood. But God has found her. How? By Christ, who took and takes her place, or more precisely by God who took and takes her place in Christ.

At this point a contest of joyous exchange takes place. Because Christ is God and man, and has never sinned, and because his sanctity is unconquerable, eternal, and almighty, he takes possession of the sins of the believing soul by virtue of her wedding-ring, namely faith, and acts just as if he had committed those sins himself. ${ }^{19}$

Why "contest of joyous exchange," and not only “joyous exchange"? ${ }^{20}$ Why not just "exchange" and "joy"? Because God must prevail against the human in his favour. The human strives for his freedom, for all kinds of freedom which he can imagine, but not for this particular freedom which, leaving him behind, places him before God in Christ's place. The human being does not strive for it and does not reach it. God does it for him.

$19 \$ 12$, rev. In German: "Hier erhebt sich nun der fröhliche Wechsel und Streit. Weil Christus Gott und Mensch ist, der noch nie gesündigt hat, und seine Frommheit unüberwindlich, ewig und allmächtig ist, so macht er denn die Sünde der gläubigen Seele durch ihren Brautringdas ist der Glaube - sich selbst zu eigen und nicht anders tut, denn als hätte er sie getan." The English translation, strangely, has "exchanges" (plural) for "Wechsel."

20 The Latin text is very explicit in this respect! It speaks of a "blessed battle that leads to victory, salvation and redemption," and a bit later of "a mighty duel or battle." Martin Luther, "The Freedom of a Christian," in Martin Luther's Basic Theological Writings, ed. William R. Russell, trans. Mark Tranvik (Minneapolis: Fortress Press, 2012), 409-10. 


\section{Conclusion}

We began our interpretation of Luther's famous text with an ecumenical intention, or rather with an ecumenical perspective: Are there not points of contact between Orthodox and Protestant theology with regard to the understanding of the human being? Thereupon Martin Luther should be questioned.

His book On the Freedom of a Christian served as a basis, because in it the concept of freedom - one of the crucial concepts of philosophical and theological anthropology - is at the center. We started with a first reading and became more and more involved in a movement of thought that caught us and took us away from our expectations of understanding what freedom is. So, a second and a third reading became necessary.

Although it cannot be denied that the modern understanding of freedom, with its emphasis on autonomy and individual responsibility, received decisive impulses not only from humanism, but also from the Reformation, it has become clear that what Luther was interested in with regard to freedom was something quite different from what modern man is so proud of: his selfdetermination. By delving deeper into the Christ event, Luther discovered that true freedom comes to man, so that he does not readily find it in himself, but instead receives it from God by letting God decide over himself. In this surrender to God, which is a surrender of oneself, man becomes aware that the freedom that matters consists in the fact that he may be man before God, freed by God from himself. So, the highest freedom before God is his unfreedom before him, in other words, the election that happens to him. It is precisely in this disharmonious, disproportionate relationship that man is man, and God is God. Outside this relationship, God is always only an image of the human (an image that man makes of God), and man is also always only an image of man (an image that man makes of himself).

True freedom is therefore a reality that does not exist otherwise: namely, that God is God and man is man, and that God may be God, and man may be man. With these insights, Luther was very far removed from what is understood in Orthodox theology as freedom, namely the divine gift which is a characteristic of the human being and which consists in the fact that he may - and should - move towards God out of the capacities that his Creator gave him and that his Redeemer ennobled for his sake.

What does this discrepancy between the two theologies mean for the ecumenical conversation, for the ecumenical encounter? It means on the one hand (as far as I see) that a proximity between Orthodox and Lutheran theology cannot be found in a concentration on the topic of freedom. Secondly, it means - and this is less trite than it sounds - that such a proximity is not to be 
looked for there either. So, is there no conceivable proximity at all in relation to the theme of "freedom"?

A hint given by Konstantinos Delikostantis in his essay on "Luther's Conception of Christian Freedom: Orthodox Insights" indicates a direction. ${ }^{21}$ At first glance, it does not seem promising at all. Delikostantis recalls the wellknown correspondence between Tübingen and Constantinople in the years 1577-1581, when Patriarch Jeremiah II "articulated his objections against the doctrine on the servum arbitrium, defending the [...] freedom of free will." "The Ecumenical Patriarch [in order to criticize Luther's thinking] underscored

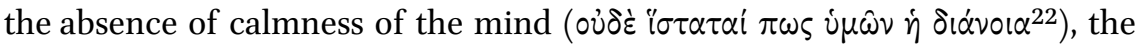

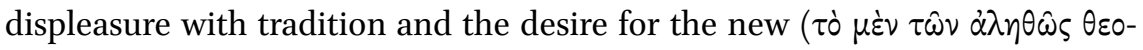

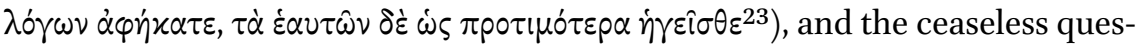
tioning and answering $[\ldots] .{ }^{\prime 24}$

The characterization that Jeremiah II gives of Luther's way of doing theology is interesting because it also - and perhaps even more so - characterizes the Orthodox way of understanding theology. And exactly there a contrast appears which is by no means less great than the one in the thematic area (in our case the understanding of freedom). The "absence of calmness of the mind," "displeasure with tradition and the desire for the new," the "ceaseless questioning and answering" refer in each case to an attitude, a psychological, and in particular a spiritual disposition which (in frontal contradiction to the criticized Lutheran attitude) constitutes on the Orthodox side the relationship with the mystery of the divine incarnation. That one, having encountered this mystery, may be "restless," refusing to allow oneself to be carried and guided by a tradition that sustains him, that one never ceases to ask questions and search for answers, all of this must be deeply alien and frightening to Orthodox piety. But could it not be that precisely in this fundamental difference of spiritual attitude, a relationship does become apparent, a communication that is not visible at all, but one that takes place in so to speak underground channels, testifying to a comparable connection to mystery? So that Luther's constant mental and spiritual "restlessness," his address to God that goes beyond all

\footnotetext{
21 For the following quotes see: 102.

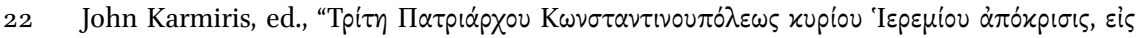

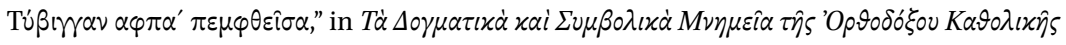

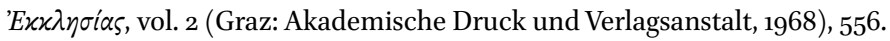

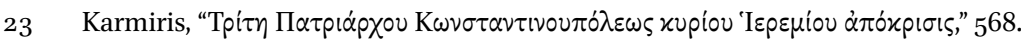

24 Vasilios N. Makrides, "Ohne Luther. Überlegungen zum Fehlen einer Reformators im Orthodoxen Christentum," in Luther zwischen den Kulturen. Zeitgenossenschaft Weltwirkung, ed. Hans Medick and Peer Schmidt (Göttingen: Vandenhoeck \& Ruprecht, 2004), 333
} 
"protection" of tradition, and his infinite searching, would also be an experience of God's mysterious turning toward the world; indeed, even more: an expression of that peace that "surpasses all understanding," - peace as the realm in which man is constantly searching for God because he knows that God has already found him?

Indeed, in the course of our three readings, have we not gained a very particular impression, namely that - beyond all intellectual efforts and knowledge here a theology is more and more formed and carried by the experience of an encounter with God; an experience in relation to which all theology is retroactive, because it does nothing but follow this mystery, letting itself be drawn more and more into it? On this level, the proximity between Orthodox and Protestant theology is perhaps much greater than what the strict concentration on the discussed and "negotiated" topics, which are often regarded controversially, would lead one to expect.

This would then have far-reaching consequences for ecumenical dialogue. Its goal would be less the attempt to achieve rapprochement or even agreement with regard to certain theological points of contention, but rather the perception and recognition of what piety (understood as connection with the divine or divine-human mystery) means also in the other tradition in its living (because lived) coherence and radiance.

\section{References}

Baeck, Leo. "Mystery and Commandment." In Judaism and Christianity, 171-85. Philadelphia: The Jewish Publication Society of America, 196o.

Baeck, Leo. "Geheimnis und Gebot." In Wege im Judentum. Aufsätze und Reden, 33-48. Berlin: Schocken, 1933.

Der große Duden, Etymologie. Herkunftswörterbuch der deutschen Sprache. Mannheim: Dudenverlag, 1963.

Jüngel, Eberhard. Zur Freiheit eines Christenmenschen. Eine Erinnerung an Luthers Schrift. Munich: Kaiser, 1991.

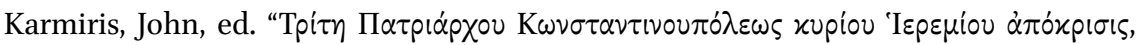

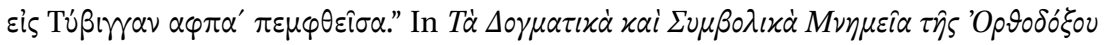

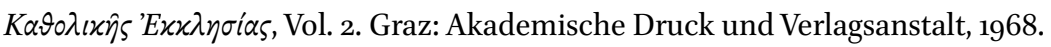

Luther, Martin. "The Freedom of a Christian." In Martin Luther's Basic Theological Writings, edited by William R. Russell, translated by Mark Tranvik, 403-27. Minneapolis: Fortress Press, 2012.

Luther, Martin. De la liberté du chrétien. Préfaces à la Bible. Translated by Philippe Büttgen. Paris: Seuil, 1996. 
Luther, Martin. "Von der Freiheit eines Christenmenschen." In Martin Luther ausgewählte Schriften, edited by Karin Bornkamm, Gerhard Ebeling, and Oswald Bayer, 2nd ed., 238-62. Frankfurt: M. Insel, 1983.

Luther, Martin. “The Freedom of a Christian." In Reformation Writings of Martin Luther, edited and translated by Bertram Lee Woolf, 1. The Basis of the Protestant Reformation:356-79. London: Lutterworth Press, $195^{2}$.

Makrides, Vasilios N. "Ohne Luther. Überlegungen zum Fehlen einer Reformators im Orthodoxen Christentum." In Luther zwischen den Kulturen. Zeitgenossenschaft Weltwirkung, edited by Hans Medick and Peer Schmidt, 318-36. Göttingen: Vandenhoeck \& Ruprecht, 2004. 